\title{
Contribution of the gas-phase reaction between hydroxyl radical and sulfur dioxide to the sulfate aerosol over West Pacific
}

Yu-Wen Chen ${ }^{1}$, Yi-Chun Chen ${ }^{1}$, Charles C.-K. Chou ${ }^{1}$, Hui-Ming Hung ${ }^{2}$, Shih-Yu Chang ${ }^{3}$, Lisa Eirenschmalz ${ }^{4}$, Michael Lichtenstern ${ }^{4}$, Helmut Ziereis ${ }^{4}$, Hans Schlager ${ }^{4}$, Greta Stratmann ${ }^{4, \#}$, Katharina

Kaiser $^{5,6}$, Johannes Schneider ${ }^{6}$, Stephan Borrmann ${ }^{5,6}$, Florian Obersteiner ${ }^{7}$, Eric Förster ${ }^{7}$, Andreas Zahn ${ }^{7}$, Wei-Nai Chen ${ }^{1}$, Po-Hsiung Lin², Shuenn-Chin Chang ${ }^{8}$, Maria Dolores Andrés Hernández ${ }^{9}$, Pao-Kuan Wang $^{1}$, and John P. Burrows ${ }^{9}$

${ }^{1}$ Research Center for Environmental Changes, Academia Sinica, Taipei, Taiwan

${ }^{2}$ Department of Atmospheric Sciences, National Taiwan University, Taipei, Taiwan

${ }^{3}$ Department of Public Health, Chung Shan Medical University, Taichung, Taiwan

${ }^{4}$ Institute of Atmospheric Physics, German Aerospace Center, Wessling, Germany

${ }^{5}$ Institute for Atmospheric Physics, Johannes Gutenberg-University, Mainz, Germany

${ }^{6}$ Max Planck Institute for Chemistry, Mainz, Germany

${ }^{7}$ Institute of Meteorology and Climate Research, Karlsruhe Institute of Technology, Karlsruhe, Germany

${ }^{8}$ Environmental Protection Administration, Taipei, Taiwan

${ }^{9}$ Institute of Environmental Physics, University Bremen, Bremen, Germany

\# Now at German Electron Synchrotron, Hamburg, Germany

Correspondence to: Yi-Chun Chen (yichunchen@gate.sinica.edu.tw) and Charles C.-K. Chou (ckchou@gate.sinica.edu.tw) 
Abstract. Sulfate is among the major components of atmospheric aerosols or fine particulate matters. Aerosols loaded with sulfate result in low air quality, damage to ecosystems, and influences on climate change. Sulfate aerosols could originate from that directly emitted to the atmosphere and that produced by atmospheric physicochemical processes. The latter is generated from sulfur dioxide $\left(\mathrm{SO}_{2}\right)$ via oxidation either in the gas phase reactions or in the aqueous phase. Several mechanisms of $\mathrm{SO}_{2}$ oxidation have been proposed, but the differentiation of the various mechanisms and identification of the sources remain challenging. To meet this need, a new method to estimate the contribution of the gas-phase reaction between hydroxyl radical $(\mathrm{OH})$ and $\mathrm{SO}_{2}$ to the sulfate aerosol is proposed and investigated. Briefly, we consider the $\mathrm{OH}$-reaction rates of the respective trace gases that compete for $\mathrm{OH}$ radicals with $\mathrm{SO}_{2}$ in the troposphere, and estimate the fraction of $\mathrm{SO}_{2}-\mathrm{OH}$ reaction in the total $\mathrm{OH}$ reactivity. Then the relationship between sulfate concentration and the $\mathrm{SO}_{2}-\mathrm{OH}$ reaction is analyzed statistically to investigate the sources of sulfate in aerosols. We test this method using the data from ground-based observations and aircraft measurements made during the Effect of Megacities on the transport and transformation of pollutants on the Regional to Global scales in Asia (EMeRGe-Asia) over the western Taiwan and West Pacific regions. Our results show that the estimated $\mathrm{SO}_{2-}$ $\mathrm{OH}$ reactivity fraction is well-correlated with sulfate concentration. The sulfate production from $\mathrm{SO}_{2}-\mathrm{OH}$ reaction accounts for approximately $30 \%$ of the total sulfate in aerosols collected at the surface and near-surface (altitude $<600 \mathrm{~m}$ ) in our study area, comparable to the estimates from other model simulations. Within its assumptions and limitations, this new method provides a valuable approach to investigate the significance of $\mathrm{SO}_{2}-\mathrm{OH}$ reaction regionally and globally. 


\section{Introduction}

Sulfate aerosol is a dominant component of particulate matters that significantly influences environmental issues, such as air quality, climate change, human health, and acid deposition. Sulfate is an important part of acid rain and ecosystem acidification, resulting from sulfur deposition (Greaver et al., 2012; Gorham et al., 1984). Using the average sulfate concentrations measured from five cities in western Taiwan during 2017 - 2020, reported by the Environmental Protection Administration of Taiwan, sulfate accounts for approximately $20 \%$ by weight of atmospheric particulate matters with a diameter less than 2.5 micrometers $\left(\mathrm{PM}_{2.5}\right)$. air pollution and improves air quality and human health. Sulfate aerosol can be divided into two categories known as primary sulfate and secondary sulfate. The major sources of primary sulfate include sea sprays, thermal power plants, and volcanic eruptions (Allen et al., 2002), whereas sulfur dioxide $\left(\mathrm{SO}_{2}\right)$ is the dominant precursor of secondary sulfate through gas-phase oxidation and aqueous-phase oxidation (Stockwell et al., 2012).

There are primarily two mechanisms by which $\mathrm{SO}_{2}$ is oxidized in the atmosphere. These comprise both gas-phase and aqueousphase reactions. Though oxygen $\left(\mathrm{O}_{2}\right)$ is the most abundant oxidant in the troposphere, the significant energy barrier of the $\mathrm{SO}_{2}-\mathrm{O}_{2}$ endothermic reaction slows the reaction rate at atmospheric temperatures, making the reaction of $\mathrm{O}_{2}$ with $\mathrm{SO}_{2}$ of minor importance (Hindiyarti et al., 2007). Similarly, the reaction rate coefficients of oxidation of $\mathrm{SO}_{2}$ with ozone $\left(\mathrm{O}_{3}\right)$ and the hydroperoxyl radical $\left(\mathrm{HO}_{2}\right)$ are also of negligible importance. Hydroxyl radical $(\mathrm{OH})$, though having concentrations much smaller than that of $\mathrm{O}_{2}$, is the most important gas-phase oxidant for $\mathrm{SO}_{2}$ oxidation (Stockwell and Calvert, 1983). $\mathrm{SO}_{2}$ is first oxidized to $\mathrm{HOSO}_{2}$ by a termolecular reaction involving an inert reaction partner (M) to take up excess kinetic energy. $\mathrm{HOSO}_{2}$ 
then reacts with $\mathrm{O}_{2}$ in the air to form sulfur trioxide $\left(\mathrm{SO}_{3}\right)$ and release an $\mathrm{HO}_{2}$. Other oxidants that could also oxidize $\mathrm{SO}_{2}$ include stabilized Criegee intermediates (Boy et al., 2013; Kurtén et al., 2011; Ye et al., 2018), organic peroxy radicals $\left(\mathrm{RO}_{2}\right.$, where $\mathrm{R}$ is an unspecified organic group) (Kurtén et al., 2011; Kan et al., 1981), and superoxide ions $\left(\mathrm{O}_{2}^{-}\right)$(Tsona et al., 2018). $\mathrm{SO}_{3}$ then reacts with water vapor $\left(\mathrm{H}_{2} \mathrm{O}\right)$ in the gas phase to form sulfuric acid $\left(\mathrm{H}_{2} \mathrm{SO}_{4}\right)$. $\mathrm{SO}_{3}$ may also react directly with $\mathrm{H}_{2} \mathrm{O}$ on the wet surface of aerosols or rain droplets to form $\mathrm{H}_{2} \mathrm{SO}_{4}$.

In contrast to the gas phase oxidation of $\mathrm{SO}_{2}$ in the atmosphere, the aqueous-phase oxidation mechanisms of $\mathrm{SO}_{2}$ are not as well understood. This is in part related to the relatively high solubility of $\mathrm{SO}_{2}$ and large dissociation equilibrium constants. Specifically, $\mathrm{SO}_{2}$ is soluble, having a Henry's Law constant of approximately 1.2 to $1.5 \mathrm{~mol} \mathrm{~kg}^{-1} \cdot \mathrm{bar}^{-1}$ (Hoffmann and Jacob, 1984; Sander et al., 2006; Dean, 1992). It dissociates to bisulfite ions $\left(\mathrm{HSO}_{3}{ }^{-}\right)$and sulfite ions $\left(\mathrm{SO}_{3}{ }^{2-}\right)$ in an aqueous solution. A variety of plausible pathways to form $\mathrm{SO}_{2} \cdot \mathrm{H}_{2} \mathrm{O}, \mathrm{HSO}_{3}{ }^{-}$, and $\mathrm{SO}_{3}{ }^{2-}$ have been proposed. For example, dissolved $\mathrm{O}_{3}$ is reported to oxidize dissolved $\mathrm{SO}_{2}$ with a rate coefficient depending significantly on the $\mathrm{pH}$ of the solution (Maahs, 1983; Hoyle et al., 2016). Moreover, in the presence of some transition metals acting as catalysts, such as iron ions $\left(\mathrm{Fe}^{3+}\right)$ and manganese ions $\left(\mathrm{Mn}^{2+}\right)$, dissolved $\mathrm{O}_{2}$ can oxidize $\mathrm{SO}_{2}$ efficiently (Herrmann et al., 2000; Harris et al., 2013; Brandt and van Eldik, 1995). Hydrogen peroxide $\left(\mathrm{H}_{2} \mathrm{O}_{2}\right)$ (Kunen et al., 1983) and organic peroxides (Wang et al., 2019; Dovrou et al., 2019) are also soluble and important oxidants in aqueous solutions such as tropospheric aerosols and rain droplets. They react with $\mathrm{HSO}_{3}{ }^{-}$ions to form $\mathrm{SO}_{4}{ }^{2-}$ ions. The $\mathrm{SO}_{2}$ related dissociated sulfur-containing ions are oxidized as well by the $\mathrm{OH}$ radical through chain reactions (McElroy, 1986). Besides, recent reports suggest that $\mathrm{SO}_{2}$ oxidation also occurs on interfacial surfaces of acidic micro-droplets in the absence of other oxidants at $\mathrm{pH}<3.5$ (Hung et al., 2018), and that nitrogen dioxide $\left(\mathrm{NO}_{2}\right)$ can oxidize $\mathrm{SO}_{2}$ in droplets in the presence of $\mathrm{NH}_{3}$ (Ge et al., 2019). 
Despite the progress made on our understanding of the mechanisms by which $\mathrm{SO}_{2}$ is oxidized in the gas-phase and aqueousphase, the contributions of the respective mechanisms to the total atmospheric sulfate concentrations remain unclear. This research aims to improve the current understanding of $\mathrm{SO}_{2}$ gas-phase oxidation by enabling the fraction of gas phase and thus also aqueous phase oxidation to be estimated accurately. We develop an approach that addresses the competition for key atmospheric oxidants between $\mathrm{SO}_{2}$ and other important trace gases. Several assumptions and approximations are made to determine the fraction of $\mathrm{OH}$ reacting with $\mathrm{SO}_{2}$ in the gas phase. This we call the gas-phase reaction rate fraction and is denoted as $f_{\text {SO2-OH }}$ hereafter. With the ground observation in Taiwan and aircraft measurements from EMeRGe-Asia field campaign on-board the HALO research aircraft of DLR (HALO, https://www.dlr.de/content/de/missionen/halo.html), the values of $f_{\text {so2- }}$ $\mathbf{O H}$ at the surface and in the air are calculated, which are further utilized to estimate the contribution of the $\mathrm{SO}_{2}-\mathrm{OH}$ reaction to the total production of sulfate. This method is applied to areas within Taiwan and outside of Taiwan to verify its reliability and versatility.

\section{Data description}

\subsection{EMeRGe-Asia data}

The Effect of Megacities on the transport and transformation of pollutants on the Regional to Global scales over Asia (EMeRGe-Asia) was a field experiment led by the University of Bremen, Germany, conducted in collaboration with Academia Sinica, Taiwan. The EMeRGe-Asia aircraft field campaign took place from Taiwan, from March $10^{\text {th }}$ to April $9^{\text {th }}$ in 2018. This field campaign investigated the composition and influence of pollution plumes from major population centers in Eastern and 
analyzed in this study. VOCs measured during the campaign included formaldehyde $\left(\mathrm{CH}_{2} \mathrm{O}\right)$, methanol $\left(\mathrm{CH}_{3} \mathrm{OH}\right)$, acetonitrile $\left(\mathrm{CH}_{3} \mathrm{CN}\right)$, acetaldehyde $\left(\mathrm{CH}_{3} \mathrm{CHO}\right)$, acetone $\left(\mathrm{CH}_{3} \mathrm{OCH}_{3}\right)$, isoprene $\left(\mathrm{C}_{5} \mathrm{H}_{8}\right)$, benzene $\left(\mathrm{C}_{6} \mathrm{H}_{6}\right)$, toluene $\left(\mathrm{C}_{7} \mathrm{H}_{8}\right)$, and xylene dataset if there is no specific clarification. In addition, the altitudes of airmasses are rounded to hundred meters for classification.

Although most of the measurements during the campaign were taken over a large area of the West Pacific, from the Philippines

to Japan, there were many regular measurements made over Western Taiwan, typically at an altitude of approximately $600 \mathrm{~m}$.

This study focuses on this area and these altitudes. Measurements in this area were mainly carried out between 8:00 to 17:00 (in local standard time, LST); sparse measurements performed outside this period are excluded from the 1-minute average dataset.

\subsection{Surface observational data}

Hourly ambient concentrations of trace gases, including $\mathrm{CO}, \mathrm{SO}_{2}, \mathrm{NO}, \mathrm{NO}_{2}, \mathrm{NO}_{\mathrm{x}}$, and $\mathrm{O}_{3}$, measured at the air quality stations of the Taiwan Environmental Protection Administration (EPA), are analyzed in this study. The hourly data observed between 8:00 to 17:00 LST from March $17^{\text {th }}$ to April $7^{\text {th }}$ of 2018 are included in our analyses to compare the surface observations with the airborne measurements. Further information on the instrumentation at the surface stations is listed in Table S1. In addition, samples of fine particulate matters (i.e., $\mathrm{PM}_{2.5}$ ) were collected at 11 sites distributed in central western Taiwan during the campaign period (from March $13^{\text {th }}$ to March $31^{\text {st }}$, 2018). The chemical composition of the $\mathrm{PM}_{2.5}$ samples was analyzed in the laboratories of RCEC, Academia Sinica, and the daytime (8:00 to 19:00 LST) sulfate concentration is used in this study. The field sampling and in-lab chemical analyses are as described in Salvador and Chou (2014). The geographic locations where we sampled $\mathrm{PM}_{2.5}$ are illustrated in Fig. S2. 


\section{Data analysis and assumptions}

In this study, $\mathrm{OH}$ radical is assumed to be the dominant tropospheric oxidant of $\mathrm{SO}_{2}$ in the gas-phase. It is challenging to quantify the reaction rate of $\mathrm{SO}_{2}-\mathrm{OH}$ oxidation directly as sophisticated instruments are necessary to accurately measure $\mathrm{OH}$ radicals. Though model simulation provides information about $\mathrm{OH}$ radical concentration, discrepancies remain between model results and observations (e.g., Griffith et al., 2016; Lew et al., 2020). OH oxidizes not only $\mathrm{SO}_{2}$ but also many other trace gases in the air, such as methane $\left(\mathrm{CH}_{4}\right), \mathrm{CO}, \mathrm{NO}, \mathrm{NO}_{2}$, and VOCs. We examine the competition for $\mathrm{OH}$ radicals among these trace gases to estimate the fraction of $\mathrm{OH}$ reacting with $\mathrm{SO}_{2}$, i.e., $f_{\text {SO2-OH. }}$

We estimate the $f_{\text {SO2-OH }}$ as defined by Eq. (1), where $\mathrm{OH}$ reactions with major trace gases $\left(\mathrm{CH}_{4}, \mathrm{CO}, \mathrm{NO}, \mathrm{NO}_{2}\right.$, VOCs, and $\mathrm{SO}_{2}$ ) are considered. This method constrains any overestimation of $\mathrm{SO}_{2}$ oxidation rate in the absence of accurate knowledge about the concentration of $\mathrm{OH}$ radicals in air masses. The $\mathrm{OH}$-trace gas reactions are either second-order reactions $\left(\mathrm{CH}_{4}, \mathrm{CO}\right.$, $\mathrm{NO}$, and $\mathrm{NO}_{2}$ ) or third-order reactions involving air as the third body. The $\mathrm{SO}_{2}-\mathrm{OH}$ reaction is such a third-order reaction but is considered a pseudo-second-order reaction at low altitudes because of a reasonable approximation that the nitrogen $\left(\mathrm{N}_{2}\right)$ and $\mathrm{O}_{2}$ have stable concentrations over a small altitude range. As a result, Eqs. (2)-(7) describe the $\mathrm{OH}$ reaction rate of each major trace gas by three parameters, including the rate coefficient, the concentration of the trace gas, and the concentration of $\mathrm{OH}$ radical. The rate constants of these $\mathrm{OH}$ reactions are summarized in Table S2 (Burkholder et al., 2020).

$$
\begin{aligned}
& f_{\mathrm{SO} 2-\mathrm{OH}}=\frac{r_{\mathrm{SO}_{2}-\mathrm{OH}}}{r_{\mathrm{CH}_{4}-\mathrm{OH}}+r_{\mathrm{CO}-\mathrm{OH}}+r_{\mathrm{NO}-\mathrm{OH}}+r_{\mathrm{NO}_{2}-\mathrm{OH}}+r_{\mathrm{VOCS}-\mathrm{OH}+r_{\mathrm{SO}_{2}-\mathrm{OH}}}} \\
& r_{\mathrm{CH}_{4}-\mathrm{OH}}=k_{\mathrm{CH}_{4}}\left[\mathrm{CH}_{4}\right][\mathrm{OH}] \\
& r_{\mathrm{CO}-\mathrm{OH}}=k_{\mathrm{CO}}[\mathrm{CO}][\mathrm{OH}] \\
& r_{\mathrm{NO}-\mathrm{OH}}=k_{\mathrm{NO}}[\mathrm{NO}][\mathrm{OH}] \\
& r_{\mathrm{NO}_{2}-\mathrm{OH}}=k_{\mathrm{NO}_{2}}\left[\mathrm{NO}_{2}\right][\mathrm{OH}]
\end{aligned}
$$




$$
r_{\mathrm{SO}_{2}-\mathrm{OH}}=\boldsymbol{k}_{\mathrm{SO}_{2}}\left[\mathrm{SO}_{2}\right][\mathrm{OH}]
$$

Among the major trace gases considered here, VOCs are not measured at the ground-based stations of Taiwan EPA. Although the concentrations of some VOCs were measured onboard HALO and the sum of the measured concentrations may represent the majority of the VOCs to a reasonable approximation, significant uncertainty could still remain in the estimate of $f_{\text {SO2-OH }}$ in case of missing one or some of the key VOCs. Considering the challenge and difficulty of measuring all the significant VOCs, we propose a different approach. We assume that the total $\mathrm{OH}$ reactivity of VOCs (Eq. (6)) is proportional to the sum of $\mathrm{OH}$ reactivity of other trace gases (Eq. (2)-(5) and (7)), as written in Eq. (8).

$r_{\mathrm{VOCS}-\mathrm{OH}} \approx t\left(r_{\mathrm{CH}_{4}-\mathrm{OH}}+r_{\mathrm{CO}-\mathrm{OH}}+r_{\mathrm{NO}-\mathrm{OH}}+r_{\mathrm{NO}_{2}-\mathrm{OH}}+r_{\mathrm{SO}_{2}-\mathrm{OH}}\right)$

This assumption is consistent with previous observations in urban areas (Yang et al., 2017). In addition, the analysis using the measurements of the EMeRGe-Asia campaign also indicates that the total $\mathrm{OH}$ reactivity of the measured VOCs is linearly correlated to that contributed by other major gaseous pollutants, i.e., $\mathrm{CO}, \mathrm{NO}, \mathrm{NO}_{2}, \mathrm{SO}_{2}$, and $\mathrm{CH}_{4}$ (see Fig. S3). Consequently, the $f_{\text {SO2-OH }}$ is redefined as Eq. (9) by applying the above assumptions.

$f_{\mathrm{SO2}-\mathrm{OH}}=\frac{r_{\mathrm{SO}_{2}-\mathrm{OH}}}{\left(r_{\mathrm{CH}_{4}-\mathrm{OH}}+r_{\mathrm{CO}-\mathrm{OH}}+r_{\mathrm{NO}-\mathrm{OH}}+r_{\mathrm{NO}_{2}-\mathrm{OH}}+r_{\left.\mathrm{SO}_{2}-\mathrm{OH}\right) \times(1+t)}\right.}$

Because the proportional parameter "t" for OH-VOCs reactions in Eq. (9) is difficult to be determined accurately and because the observations for VOCs are not available at the ground-based stations, we further simplify Eq. (9) to Eq. (10) by ignoring that scaling factor. Thus Eq. (10) gives an approximation of $f_{\mathrm{SO2}-\mathrm{OH}}$, which is denoted as $f_{\mathrm{SO2}-\mathrm{OH}} *$ 
Eq. (10) is transformed to Eq. (11) by dividing each component in the numerator and denominator by $k_{\mathrm{SO}_{2}}\left[\mathrm{SO}_{2}\right][\mathrm{OH}]$, suggesting that the average ratios of each trace gas over $\mathrm{SO}_{2}$ are required to calculate $f_{\text {SO2-oH }}{ }^{*}$. These ratios are derived from field measurements in this study with the slope of linear regression using the least-squares method. However, the fits have significant errors for most trace gases, which means that the derived slopes might be arguable. These low correlations may result from different weather conditions, solar radiation intensity, and instrumental detection limits (see Table S1), discussed in Section 4.1. Here, it is assumed that the air parcels achieve a quasi-stationary state and the $\mathrm{O}_{3}$ concentration represents a measure of the oxidizing capacity of such air masses. This implies that the concentration of each trace gas divided by the concentration of $\mathrm{O}_{3}$ can be viewed as the relative amount of reductant. Consequently, Eq. (11) yields into Eq. (12). With this transformation, the performance of linear regression improves considerably as discussed in section 4.1.

$f_{\mathrm{SO}^{-}-\mathrm{OH}} *=\frac{1}{\left.\mathbf{k}^{\prime} \mathrm{CH}_{4} \frac{\left[\mathrm{CH}_{4}\right]}{\left[\mathrm{SO}_{2}\right]}+\mathbf{k}^{\prime} \mathrm{CO}_{\left[\mathrm{SO}_{2}\right]}\right] \mathbf{k}^{\prime} \mathrm{NO}_{\left[\mathrm{SO}_{2}\right]}\left[\mathrm{k}^{\prime} \mathrm{NO}_{2} \frac{\left[\mathrm{NO}_{2}\right]}{\left[\mathrm{SO}_{2}\right]}+1\right.}$

( $\mathrm{k}^{\prime}$ of each trace gas is the ratio of the rate coefficient of the $\mathrm{OH}$ reaction with that gas to that for $\mathrm{SO}_{2}$, i.e., $\mathrm{k}_{\mathrm{SO} 2}$.)

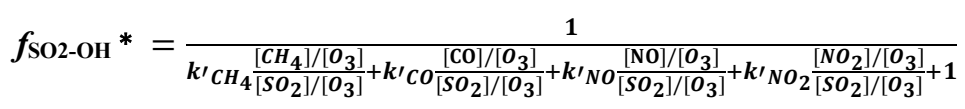

As the reaction rate of the reaction $\mathrm{CH}_{4}-\mathrm{OH}$ is less than that of reactions $\mathrm{CO}-\mathrm{OH}, \mathrm{NO}-\mathrm{OH}$, and $\mathrm{NO}_{2}-\mathrm{OH}$ (see Table $\mathrm{S} 2$ for details), the influence of the reaction of $\mathrm{CH}_{4}-\mathrm{OH}$ is assumed negligible and is thus ignored in the calculation. Consequently, only three relationships $\left(\mathrm{CO} / \mathrm{O}_{3}-\mathrm{SO}_{2} / \mathrm{O}_{3}, \mathrm{NO} / \mathrm{O}_{3}-\mathrm{SO}_{2} / \mathrm{O}_{3}\right.$, and $\left.\mathrm{NO}_{2} / \mathrm{O}_{3}-\mathrm{SO}_{2} / \mathrm{O}_{3}\right)$ are required to approximate the $f_{\mathrm{SO} 2-\mathrm{OH}^{*}}$, as shown in Eq. (13). This equation is further utilized in surface and airborne observations in this study.

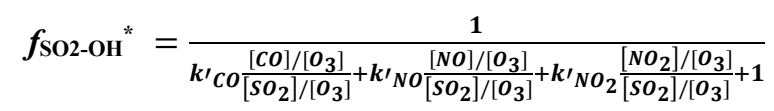


The airborne $\mathrm{NO}_{2}$ is approximated by subtracting $\mathrm{NO}$ and $\mathrm{PAN}$ from $\mathrm{NO}_{\mathrm{y}}$, assuming that $\mathrm{NO}_{\mathrm{y}}$ is composed of $\mathrm{NO}, \mathrm{NO}_{2}$, and PAN in the daytime, whereas $\mathrm{HNO}_{3}$ exists mainly in the form of particulate nitrate. However, there are fewer PAN

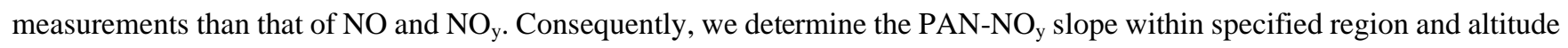
to estimate the proportion of PAN in $\mathrm{NO}_{\mathrm{y}}$ (shown in Fig. S4). Then the airborne $\mathrm{NO}_{2}$ is approximated according to Eq. (14):

Approximated airborne $\mathrm{NO}_{2}=\mathrm{NO}_{y} \times\left(1-\right.$ slope $\left._{P A N-N O_{y}}\right)-\mathrm{NO}$

\section{Results and discussion}

\subsection{Importance of normalization by $\mathrm{O}_{3}$}

We assume that the observed air plume was in steady-state, and that the ambient $\mathrm{O}_{3}$ concentration was representative of the and after the $\mathrm{O}_{3}$ normalization using data from the Tainan station located in southwestern Taiwan. Low correlations between these trace gases before the $\mathrm{O}_{3}$ normalization (Fig. 1a, 1c, 1e) are in part explained by the different weather conditions and solar radiation. For example, the photochemical consumption of air pollutants in the air masses from pollution sources traveling to the observation stations can diverge under different weather conditions, leading to different aging of the plume. The interspecies correlation significantly improved after normalization by $\mathrm{O}_{3}$ (Fig. 1b, 1d, 1f). These differences suggest that the interspecies correlation is likely subject to atmospheric oxidation, and the $\mathrm{O}_{3}$-normalization approach can efficiently reduce the relevant interferences. Taking the stations located in western Taiwan into account, $\mathrm{R}^{2}$ of $\mathrm{CO}-\mathrm{SO}_{2}, \mathrm{NO}-\mathrm{SO}_{2}$, and $\mathrm{NO}_{2}-\mathrm{SO}_{2}$ increase from $0.062,0.061$, and 0.109 to $0.468,0.428$, and 0.531 , respectively, after normalizing by ozone. The individual values for each station and trace gas are illustrated in Fig. S5. 
The normalization of the airborne measurements leads to the same effects. We divide western Taiwan into five regions, as shown in Fig. S6, where the airborne measurement is distributed. With aircraft-observed data in these regions, the trace gases$\mathrm{SO}_{2}$ relationships are determined with the $\mathrm{O}_{3}$ normalization method. The average $\mathrm{R}^{2}$ of $\mathrm{CO}-\mathrm{SO}_{2}, \mathrm{NO}-\mathrm{SO}_{2}$, and $\mathrm{NO}_{2}-\mathrm{SO}_{2}$ for the five regions increased from $0.397,0.698$, and 0.614 to $0.672,0.723$, and 0.726 , respectively, after the ozone normalization. The higher values of $\mathrm{R}^{2}$ after the $\mathrm{O}_{3}$ normalization imply that slopes have an improved accuracy which propagates into the calculation of $f_{\text {SO2-OH }}{ }^{*}$.

\subsection{Relationship between $\mathrm{SO}_{2}-\mathrm{OH}$ reaction and sulfate concentration in Western Taiwan}

We use the computed slopes from the plots of $\mathrm{CO} / \mathrm{O}_{3}-\mathrm{SO}_{2} / \mathrm{O}_{3}, \mathrm{NO} / \mathrm{O}_{3}-\mathrm{SO}_{2} / \mathrm{O}_{3}$, and $\mathrm{NO}_{2} / \mathrm{O}_{3}-\mathrm{SO}_{2} / \mathrm{O}_{3}$ to estimate the values of $f_{\text {SO2-OH }}{ }^{*}$ for surface stations by using Eq. (13), which are then compared with the sulfate concentrations. As shown in Fig. 2a, the sulfate concentration positively correlates with $f_{\mathrm{SO2}-\mathrm{OH}^{*}}{ }^{*}$ measured at 11 surface stations. This correlation implies that $\mathrm{SO}_{2}-$ $\mathrm{OH}$ reaction explains the sulfate variability to a significant extent at selected locations. The regression slopes would be close to zero if the contribution of $\mathrm{SO}_{2}-\mathrm{OH}$ reaction to sulfate was negligible. The regression intercept is explained as the amount of sulfate independent of $\mathrm{SO}_{2}-\mathrm{OH}$ reaction, e.g., primary sulfate, transported sulfate, and sulfate derived from aqueous $\mathrm{SO}_{2}$ oxidation.

The importance of the difference in weather conditions and the origin of the transported air plumes is now considered. Three periods with similar weather conditions are investigated. The weather type is considered to describe the daily synoptic weather event log, obtained from the Taiwan Atmospheric event Database (Su et al., 2018). The first period under consideration was March $13^{\text {rd }}, 14^{\text {th }}$, and $17^{\text {th }}-19^{\text {th }}$, during which the southwesterly flow of air was dominant. The second period includes March $16^{\text {th }}, 22^{\text {nd }}$, and $27^{\text {th }}$, which is under northeasterly flow. The third period comprises March $23^{\text {rd }}-26^{\text {th }}, 28^{\text {th }}$, and $29^{\text {th }}$, which contains weak synoptic weather events. The correlations of $f_{\text {SO2-OH }}{ }^{*}$ and the amount of sulfate during these three periods are 
higher than that for the entire observation period, as shown in Fig. 3. This indicates that weather conditions influence the formation of sulfate.

For the airborne observation data, we divided Western Taiwan into five regions (as shown in Fig. S6) and calculated the $f_{\text {so2- }}$ он $^{*}$ separately. A positive correlation between sulfate and $f_{\text {SO2-OH }}{ }^{*}$ is also observed in the airborne observation, as shown in Fig. 2 b. As the derived positive slope is marginally significant ( $\mathrm{p}$-value $=0.218$ ), sulfate and $\boldsymbol{f}_{\text {SO2-OH }}{ }^{*}$ analyses with adequate airborne measurement data are necessary to validate the relationship. We therefore extend the study to a larger region over the West Pacific in Sect. 4.3.

\subsection{Relationship between $\mathrm{SO}_{2}-\mathrm{OH}$ reaction and sulfate concentration over the West Pacific}

Considering aircraft speed, here a 15-second average dataset (instead of a 1-minute average in the previous analysis) is utilized to improve the spatial resolution. In addition, the data is classified according to their longitude and latitude; the data located within a $0.25^{\circ} \times 0.25^{\circ}$ gridded region is used to calculate the $f_{\mathrm{SO} 2-\mathrm{OH}}{ }^{*}$. The contribution of $\mathrm{SO}_{2}-\mathrm{OH}$ reaction is evaluated at different altitudes and regions, including Taiwan, East China Sea, and South Japan Sea, as presented in Fig. 4. A significant correlation between sulfate and $f_{\text {SO2-OH }}{ }^{*}$ is found in various regions and altitudes, and the information is presented in Table 2.

Although a strong correlation exists at different altitudes, no significant trends exist between altitudes and other variables. We expect the $f_{\text {SO2-OH }}{ }^{*}$ to decrease with height as trace gases' concentrations are generally higher near to the surface. However, the calculated maximum $f_{\text {SO2-OH }}{ }^{*}$ does not decrease with altitude. This discrepancy may result from using measurements from different locations and the existence of inversion layers, which influences the distribution of trace gases. It is noteworthy that, a special multi-altitudes $(600 \mathrm{~m}, 900 \mathrm{~m}, 1200 \mathrm{~m})$ flight mission conducted over western Taiwan on April $3^{\text {rd }}$ revealed the largest 
value of slope of sulfate vs. $f_{\text {SO2-oH }}{ }^{*}$ at $900 \mathrm{~m}$ (shown in Fig. 4 f). This phenomenon may be explained by the accumulation of trace gases below the ceiling of the boundary layer near $900 \mathrm{~m}$.

\subsection{OH-oxidation explicable sulfate percentage}

According to our hypothesis, the intercept of the plot of sulfate vs. $f_{\text {SO2-OH }}{ }^{*}$ may approximate the amount of sulfate generated by mechanisms other than the $\mathrm{SO}_{2}-\mathrm{OH}$ reaction. This includes $\mathrm{SO}_{2}$ aqueous-phase oxidation, primary source emission, and transport. For environmental policy issues, it is valuable and necessary to separate the contribution of $\mathrm{SO}_{2}$ gas-phase oxidation from the other sulfate sources. As a result, the $\mathrm{SO}_{2}$ gas-phase-produced sulfate (SGS) percentage is defined in Eq. (15), enabling us to investigate the extent of $\mathrm{SO}_{2}$ gas-phase oxidation in different areas.

$\mathrm{SO}_{2}$ gas-phase-produced sulfate (SGS) percentage $=\frac{\text { maximum sulfate in target area - intercept }}{\text { maximum sulfate in target area }} \times 100 \%$

Table 2 presents the SGS percentage in selected periods at the surface and selected altitudes/areas. The results show that SGS percentages are approximately $30 \%$ at the surface and at $600 \mathrm{~m}$ over a period of time. This result is comparable with the model simulation by Harris et al. (2013) that $76 \pm 7 \%$ of $\mathrm{SO}_{2}$ undergoes aqueous-phase oxidation, and the rest of $\mathrm{SO}_{2}$ is oxidized by $\mathrm{OH}$ radicals in the gas phase. However, for a daily analysis over a specific region, the SGS percentages for data at different altitudes vary and may be much higher than $30 \%$ (see Table 2). These high SGS cases could be related to the less amount of transported sulfate. For example, the SGS of Fig. 4d is much higher than that of Fig. 4b, although they were both measured at $300 \mathrm{~m}$. The backward trajectories using HYSPLIT provided by NOAA ARL (Stein et al., 2015; Rolph et al., 2017) in Fig S7ab show that the air masses of Fig. 4a-b passed through East China and loaded with abundant $\mathrm{SO}_{2}$ and primary sulfate, while air parcels of the case of Fig. 4c-d went across the Sea of Japan, a relatively clean area. Less transported sulfate in the air parcels could contribute to higher SGS. The high SGS at 700 and 900 m over Taiwan may also connect with low long-rangetransported sulfate (see Fig. S7c-d), and thus the importance of the $\mathrm{SO}_{2}-\mathrm{OH}$ gas-phase oxidation increase in these cases. Therefore, the amount of primary sulfate could fluctuate and impact the percentage of $\mathrm{SO}_{2}$ gas-phase-produced sulfate. 
Table 2 presents the amount of SGS and the average $\mathrm{SO}_{2}$ concentration in target areas to enable us to verify our inference of the SGS percentage. With the reported average daytime $\mathrm{OH}$ radical concentration of $8.3 \times 10^{6}$ molecules $\mathrm{cm}^{-3}$ sampling in region B from September 2004 to April 2005 (Lin et al., 2010) and the $\mathrm{SO}_{2}-\mathrm{OH}$ reaction rate coefficient of $1.7 \times 10^{-12} \mathrm{~cm}^{3}$ molecule $\mathrm{s}^{-1}$, the necessary reaction time is calculated to be approximately 3.4 hours at the surface (3/13-3/31) and 2.3 hours at an altitude of $600 \mathrm{~m}$. The near-surface reaction time for producing the amount of sulfate is adequate for short-range transport within Taiwan, which justifies our result that nearly $30 \%$ of sulfate aerosol mass results from the $\mathrm{SO}_{2}-\mathrm{OH}$ reaction.

\subsection{Characteristics of trace gases and $\mathrm{SO}_{2}$ oxidation at the surface and as a function of altitude}

The characteristics of trace gases provide additional information to investigate the possible sources of pollution plumes. For example, $\mathrm{CO}-\mathrm{NO}_{\mathrm{x}}$ at the surface and $\mathrm{CO}-\mathrm{NO}_{\mathrm{y}}$ in the air have similar correlations. As shown in Fig. 5a, the correlations between $\mathrm{CO}$ and $\mathrm{NO}_{\mathrm{x}}$ at the surface, as well as $\mathrm{CO}$ and $\mathrm{NO}_{\mathrm{y}}$ in the air, are similar. The slopes of $\mathrm{CO}-\mathrm{NO}_{\mathrm{x}}$ at the surface and $\mathrm{CO}-\mathrm{NO}_{\mathrm{y}}$ in the air are $0.057 \pm 0.0003$ and $0.050 \pm 0.002$, respectively. Though $\mathrm{NO}_{\mathrm{x}}$ does not wholly represent $\mathrm{NO}_{\mathrm{y}}$, we infer that $\mathrm{NO}_{\mathrm{x}}$ takes a significant part of $\mathrm{NO}_{\mathrm{y}}$. On the other hand, as demonstrated in Fig. 5b-c, discernible disparities exist in $\mathrm{SO}_{2}-\mathrm{CO}_{\text {and }}$ $\mathrm{SO}_{2}-\mathrm{NO}_{\mathrm{x}} / \mathrm{SO}_{2}-\mathrm{NO}_{\mathrm{y}}$ airborne to surface relationships. According to the scatter plots, the $\mathrm{SO}_{2}-\mathrm{CO}$ relationship can be generally subdivided into two categories: high $\mathrm{SO}_{2}$ to $\mathrm{CO}$ ratio and low $\mathrm{SO}_{2}$ to $\mathrm{CO}$ ratio, and so does the $\mathrm{SO}_{2}-\mathrm{NO}_{\mathrm{x}} / \mathrm{SO}_{2}-\mathrm{NO}_{\mathrm{y}}$ relationship. These two apparent features are explained by different emission types: traffic sources and industrial sources. Conforming to the Taiwan Emission Data System version 10.1 (TEDS 10.1, 2020, as listed in Table S3), the annual $\mathrm{SO}_{2}$ to $\mathrm{CO}$ emission ratio of traffic sources (line sources in the TEDS) is estimated to be $4.1 \times 10^{-4}$, and that of industrial sources lie between 0.3 to 20 , which is much higher than the ratio of traffic sources. Similar to the annual $\mathrm{SO}_{2}$ to $\mathrm{CO}$ emission ratio, the annual $\mathrm{SO}_{2}$ to $\mathrm{NO}_{\mathrm{x}}$ emission ratios of traffic sources and industrial sources are assessed to be $7.7 \times 10^{-4}$ and 0.37 to 0.79 , respectively. 
According to Fig. 5b-c, airborne trace gases have high $\mathrm{SO}_{2}$ to $\mathrm{CO}$ ratios and high $\mathrm{SO}_{2}$ to $\mathrm{NO}_{\mathrm{y}}$ ratios. These relationships imply

that industrial sources may significantly contribute more to the airborne trace gases over Taiwan than traffic sources during the spring and the intermonsoon weather. The industrial-produced plumes are transported to the upper air more quickly through the tall stacks of these sources and the thermal driving force than traffic emissions released close to the surface. Here, we classify the EPA surface stations into five regions defined in Section 4.1 and calculate the average $f_{\text {SO2-oH }}{ }^{*}$ for each region. As shown in Fig. 6 , the orders of $f_{\mathrm{SO2}-\mathrm{OH}}{ }^{*}$ at the surface and in the air are $\mathrm{B}=\mathrm{C}>\mathrm{E}>\mathrm{D}>\mathrm{A}$ and $\mathrm{E}>\mathrm{B}>\mathrm{D}>\mathrm{C}>\mathrm{A}$, respectively. Region

B has high rate fractions at the surface and in the air since a massive coal-fired power plant and vast industrial areas stand in region B. The distribution of $f_{\mathrm{SO2}-\mathrm{OH}}{ }^{*}$ coincides with the locations of massive power plants and industrial areas, indicating that industrial sources significantly influence $f_{\text {SO2-OH }}{ }^{*}$ and the sulfate concentrations. Nonetheless, region $\mathrm{E}$ has the highest $f_{\text {SO2- }}$ $\mathbf{O H}^{*}$ in the air but is the third highest at the surface. In addition to a coal-fired power plant and industrial areas located in region $\mathrm{E}$, the other reason for the observed behavior could be the strong prevailing north wind, which transports $\mathrm{SO}_{2}$ from upwind sources to southern areas and leads to higher sulfate concentration in region E (see Fig. S8 for average wind speeds in each region). Nevertheless, limited measurements from surface stations and in the air might not represent the whole region. More observations are necessary to verify our arguments.

\section{Conclusions}

Our study investigates and presents an approach to evaluate the contribution of $\mathrm{SO}_{2}-\mathrm{OH}$ gas-phase reaction to the total sulfate.

We use knowledge of the reactions between $\mathrm{OH}$ and the major trace gases $\left(\mathrm{SO}_{2}, \mathrm{CO}, \mathrm{NO}, \mathrm{NO}_{2}\right)$ to estimate the fraction of $\mathrm{OH}$ reactivity due to $\mathrm{SO}_{2}-\mathrm{OH}$ reaction, $\boldsymbol{f}_{\mathrm{SO2}-\mathrm{OH}}{ }^{*}$. The surface observations over western Taiwan and airborne EMeRGe-Asia field measurements over the West Pacific are analyzed. This study shows that the value of $\boldsymbol{f}_{\text {SO2-OH }}{ }^{*}$ has a significant correlation with the sulfate concentration at the surface and $600 \mathrm{~m}$ altitude above Taiwan. This correlation also appears in different areas and 
altitudes, though more observational data are needed to confirm the significance. Based on the relationship between sulfate

reaction, which could vary significantly with the influences of primary emission or long-range transported sulfate. Meanwhile, the observations indicate that $\mathrm{SO}_{2}$ and sulfate from $\mathrm{SO}_{2}-\mathrm{OH}$ reaction in the airspace of western Taiwan primarily come from industrial sources, such as thermal power plants and industrial areas, conforming with the distribution of $f_{\mathrm{SOz}-\mathrm{OH}}{ }^{*}$. Our results underline the importance of $\mathrm{SO}_{2}-\mathrm{OH}$ gas-phase oxidation in sulfate formation, and demonstrate that the method proposed can potentially be applied to other regions and under different meteorological conditions taking the assumptions and limitations into account.

\section{Data availability}

EMeRGe-Asia data are archived in a public password-protected data archive (https://halo-db.pa.op.dlr.de). Taiwan EPA station data can be found in the environmental open data platform of EPA, Taiwan (https://data.epa.gov.tw). TEDS 10.1 data 315 are available on the Taiwan Emission Data System website managed by Taiwan EPA (https://teds.epa.gov.tw/TEDS.aspx).

\section{Author contributions}

YWC analyzed the data. YWC, YCC, and CKC prepared for the manuscript. YCC and CKC supervised the work. HMH advised on the study. JPB conceived the EMeRGe project and led the field campaign. The other authors provided measurement data. All the authors read and improved the manuscript.

\section{Competing interests}

The authors declare that they have no conflict of interest. 


\section{Acknowledgments}

The authors are grateful to Prof. Shaw C. Liu and Prof. Chun-Chieh Wu for their assistance in the initial stage of the EMeRGe project in Taiwan. Special thanks also go to Deputy Minister Hung-The Tsai at Taiwan EPA for his help in the coordination of various governmental agencies in Taiwan, which is of vital importance to allow the special HALO flight missions performed in the air space of Taiwan. This study is financially supported by Academia Sinica and the Ministry of Science and Technology, Taiwan, under grants 106-3114-M-001-001-A and 105-2111-M-001-005-MY3. The High Altitude and Long Range Research

Aircraft (HALO) is a German government research aircraft operated for the German research community by the German Aerospace Center (DLR) from Oberpfaffenhofen. The Effect of Megacities on the Transport and Transformation of Pollutants at Regional to Global Scales (EMeRGe) is a research mission selected by the German research foundation (DFG) for its HALO SPP 1294 infrastructure research program. The flight costs of the EMeRGe campaign were funded by a consortium comprising the DFG, which supports the German university costs, the Research Center for Environmental Changes, Academia Sinica,

Taiwan, the DLR Institute of Atmospheric Physics, DLR-IAP, the Karlsruhe Institute of Technology, KIT, the Max Planck Society, MPG, and Research Centre Jülich, FZ-J. The EMeRGe research undertaken at the University of Bremen and the DLRIAP for EMeRGe was funded primarily by the University of Bremen and DLR respectively and in small part by the DFG. The University of Bremen also thanks the Max Planck Institute for Chemistry (MPIC) for support for EMeRGe. KK and JS acknowledge funding by the DFG under project No. 316589531. The authors gratefully acknowledge the NOAA Air Resources 


\section{References}

Allen, A. G., Oppenheimer, C., Ferm, M., Baxter, P. J., Horrocks, L. A., Galle, B., McGonigle, A. J. S., and Duffell, H. J., Primary sulfate aerosol and associated emissions from Masaya Volcano, Nicaragua, J. Geophys. Res., 107, 4682, doi:10.1029/2002JD002120, 2002.

Boy, M., Mogensen, D., Smolander, S., Zhou, L., Nieminen, T., Paasonen, P., Plass-Dülmer, C., Sipilä, M., Petäjä, T., Mauldin, L., Berresheim, H., and Kulmala, M.: Oxidation of SO2 by stabilized Criegee intermediate (sCI) radicals as a crucial source for atmospheric sulfuric acid concentrations, Atmos. Chem. Phys., 13, 3865-3879, https://doi.org/10.5194/acp-13-3865-2013, 2013.

Brandt, C., and van Eldik, R.: Transition Metal-Catalyzed Oxidation of Sulfur(IV) Oxides. Atmospheric-Relevant Processes and Mechanisms, Chem. Rev., 95, 119-190, https://doi.org/10.1021/cr00033a006, 1995.

Brito, J. and Zahn, A.: An unheated permeation device for calibrating atmospheric VOC measurements, Atmos. Meas. Tech., 4, 2143-2152, https://doi.org/10.5194/amt-4-2143-2011, 2011.

Burkholder, J. B., Sander, S. P., Abbatt, J. P. D., Barker, J. R., Cappa, C., Crounse, J. D., Dibble, T. S.; Huie, R. E.; Kolb, C. E.; Kurylo, M. J.; Orkin, V. L.; Percival, C. J.; Wilmouth, D. M.; Wine, P. H.: Chemical kinetics and photochemical data for use in atmospheric studies; evaluation number 19, Pasadena, CA: Jet Propulsion Laboratory, National Aeronautics and Space Administration, 2020.

Dean, J. A.: Lange's handbook of chemistry, McGraw-Hill New York, 1992.

360 Dovrou, E., Rivera-Rios, J. C., Bates, K. H., and Keutsch, F. N.: Sulfate Formation via Cloud Processing from Isoprene Hydroxyl Hydroperoxides (ISOPOOH), Env. Sci. \& Technol., 53, 12476-12484, https://doi.org/10.1021/acs.est.9b04645, 2019.

Ge, S., Wang, G., Zhang, S., Li, D., Xie, Y., Wu, C., Yuan, Q., Chen, J., and Zhang, H.: Abundant NH3 in China Enhances Atmospheric HONO Production by Promoting the Heterogeneous Reaction of SO2 with NO2, Env. Sci. \& Technol., 53, 14339-14347, https://doi.org/10.1021/acs.est.9b04196, 2019.

Gorham, E., Martin, F. B., and Litzau, J. T.: Acid Rain: Ionic Correlations in the Eastern United States, 1980-1981, Science, 225, 407, https://doi.org/10.1126/science.225.4660.407, 1984.

Greaver, T. L., Sullivan, T. J., Herrick, J. D., Barber, M. C., Baron, J. S., Cosby, B. J., Deerhake, M. E., Dennis, R. L., Dubois, J.-J. B., Goodale, C. L., Herlihy, A. T., Lawrence, G. B., Liu, L., Lynch, J. A., and Novak, K. J.: Ecological effects of nitrogen 
and sulfur air pollution in the US: what do we know?, Front. Ecol. Envrion., 10, 365-372, https://doi.org/10.1890/110049, 2012.

Harris, E., Sinha, B., van Pinxteren, D., Tilgner, A., Fomba, K. W., Schneider, J., Roth, A., Gnauk, T., Fahlbusch, B., Mertes, S., Lee, T., Collett, J., Foley, S., Borrmann, S., Hoppe, P., and Herrmann, H.: Enhanced Role of Transition Metal Ion Catalysis During In-Cloud Oxidation of SO2, Science, 340, 727, https://doi.org/10.1126/science.1230911, 2013.

Herrmann, H., Ervens, B., Jacobi, H. W., Wolke, R., Nowacki, P., and Zellner, R.: CAPRAM2.3: A Chemical Aqueous Phase Radical Mechanism for Tropospheric Chemistry, J. Atoms. Chem., 36, 231-284, https://doi.org/10.1023/A:1006318622743, 2000.

Hindiyarti, L., Glarborg, P., and Marshall, P.: Reactions of SO3 with the O/H Radical Pool under Combustion Conditions, J. Phys. Chem. A, 111, 3984-3991, https://doi.org/10.1021/jp067499p, 2007.

Hoffmann, M. R., and Jacob, D. J.: Kinetics and mechanisms of the catalytic oxidation of dissolved sulfur dioxide in aqueous solution: An application to nighttime fog water chemistry, 1984.

Hoyle, C. R., Fuchs, C., Järvinen, E., Saathoff, H., Dias, A., El Haddad, I., Gysel, M., Coburn, S. C., Tröstl, J., Bernhammer, A. K., Bianchi, F., Breitenlechner, M., Corbin, J. C., Craven, J., Donahue, N. M., Duplissy, J., Ehrhart, S., Frege, C., Gordon, H., Höppel, N., Heinritzi, M., Kristensen, T. B., Molteni, U., Nichman, L., Pinterich, T., Prévôt, A. S. H., Simon, M., Slowik, J. G., Steiner, G., Tomé, A., Vogel, A. L., Volkamer, R., Wagner, A. C., Wagner, R., Wexler, A. S., Williamson, C., Winkler, P. M., Yan, C., Amorim, A., Dommen, J., Curtius, J., Gallagher, M. W., Flagan, R. C., Hansel, A., Kirkby, J., Kulmala, M., Möhler, O., Stratmann, F., Worsnop, D. R., and Baltensperger, U.: Aqueous phase oxidation of sulphur dioxide by ozone in cloud droplets, Atmos. Chem. Phys., 16, 1693-1712, https://doi.org/10.5194/acp-16-1693-2016, 2016.

Hung, H.-M., Hsu, M.-N., and Hoffmann, M. R.: Quantification of SO2 Oxidation on Interfacial Surfaces of Acidic Micro-

Droplets: Implication for Ambient Sulfate Formation, Env. Sci. \& Technol., 52, 9079-9086, https://doi.org/10.1021/acs.est.8b01391, 2018.

Kan, C. S., Calvert, J. G., and Shaw, J. H.: Oxidation of sulfur dioxide by methylperoxy radicals, J. Phys. Chem., 85, https://doi.org/1126-1132, 10.1021/j150609a011, 1981.

Kunen, S. M., Lazrus, A. L., Kok, G. L., and Heikes, B. G.: Aqueous oxidation of SO2 by hydrogen peroxide, J. Geophys.

Res. Oceans, 88, 3671-3674, https://doi.org/10.1029/JC088iC06p03671, 1983.

Kurtén, T., Lane, J. R., Jørgensen, S., and Kjaergaard, H. G.: A Computational Study of the Oxidation of SO2 to SO3 by GasPhase Organic Oxidants, J. Phys. Chem. A, 115, 8669-8681, https://doi.org/10.1021/jp203907d, 2011. 
Lew, M. M., Rickly, P. S., Bottorff, B. P., Reidy, E., Sklaveniti, S., Léonardis, T., Locoge N., Dusanter S., Kundu S., Wood E., and Stevens, P. S.: OH and $\mathrm{HO} 2$ radical chemistry in a midlatitude forest: measurements and model comparisons, Atmos. Chem. Phys., 20, 9209-9230, https://doi.org/10.5194/acp-20-9209-2020, 2020.

Lin, Y. C., Cheng, M. T., Lin, W. H., Lan, Y.-Y., and Tsuang, B.-J.: Causes of the elevated nitrate aerosol levels during episodic days in Taichung urban area, Taiwan, Atoms. Environ., 44, 1632-1640, https://doi.org/10.1016/j.atmosenv.2010.01.039, 2010.

Luke, W. T., Kelley, P., Lefer, B. L., Flynn, J., Rappenglück, B., Leuchner, M., Dibb, J. E., Ziemba, L. D., Anderson, C. H., and Buhr, M.: Measurements of primary trace gases and NOY composition in Houston, Texas, Atoms. Environ., 44, 40684080, https://doi.org/10.1016/j.atmosenv.2009.08.014, 2010.

Maahs, H. G.: Kinetics and mechanism of the oxidation of S(IV) by ozone in aqueous solution with particular reference to SO2 conversion in nonurban tropospheric clouds, J. Geophys. Res. Oceans, 88, 10721-10732, https://doi.org/10.1029/JC088iC15p10721, 1983.

410 McElroy, W. J.: The aqueous oxidation of $\mathrm{SO} 2$ by $\mathrm{OH}$ radicals, Atoms. Environ. (1967), 20, 323-330, https://doi.org/10.1016/0004-6981(86)90034-X, 1986.

Rolph, G., Stein, A., and Stunder, B.: Real-time Environmental Applications and Display sYstem: READY. Environmental Modelling \& Software, 95, 210-228, https://doi.org/10.1016/j.envsoft.2017.06.025, 2017.

Salvador, C. M., and Chou, C. C. K.: Analysis of semi-volatile materials (SVM) in fine particulate matter, Atoms. Environ., 95, 288-295, https://doi.org/10.1016/j.atmosenv.2014.06.046, 2014.

Sander, S., Golden, D., Kurylo, M., Moortgat, G., Wine, P., Ravishankara, A., Kolb, C., Molina, M., Finlayson-Pitts, B., and Huie, R.: Chemical kinetics and photochemical data for use in atmospheric studies evaluation number 15, Pasadena, CA: Jet Propulsion Laboratory, National Aeronautics and Space, 2006.

Sander, S. P., and Seinfeld, J. H.: Chemical kinetics of homogeneous atmospheric oxidation of sulfur dioxide, Env. Sci. \&

Technol., 10, 1114-1123, 1976.

Schulz, C., Schneider, J., Amorim Holanda, B., Appel, O., Costa, A., Sá, S. S. D., Dreiling, V., Fütterer D., Jurkat-Witschas, T., Klimach, T., Knote, C., Krämer M., Martin, S. T., Mertes, S., Pöhlker M. L., Sauer, D., Voigt, C., Walser, A., Weinzierl, B., Ziereis, H., Zöger M., Andreae, M. O., Artaxo, P., Machado, L. A. T., Pöschl U., Wendisch, M., and Borrmann, S.: Aircraftbased observations of isoprene-epoxydiol-derived secondary organic aerosol (IEPOX-SOA) in the tropical upper troposphere over the Amazon region, Atmos. Chem. Phys., 18, 14979-15001, https://doi.org/10.5194/acp-18-14979-2018, 2018. 
Speidel, M., Nau, R., Arnold, F., Schlager, H., and Stohl, A.: Sulfur dioxide measurements in the lower, middle and upper troposphere: Deployment of an aircraft-based chemical ionization mass spectrometer with permanent in-flight calibration, Atoms. Environ., 41, 2427-2437, https://doi.org/10.1016/j.atmosenv.2006.07.047, 2007.

Stein, A.F., Draxler, R.R, Rolph, G.D., Stunder, B.J.B., Cohen, M.D., and Ngan, F.: NOAA's HYSPLIT atmospheric transport and dispersion modeling system, Bull. Amer. Meteor. Soc., 96, 2059-2077, http://sci-hub.tw/10.1175/BAMS-D-14-00110.1, 2015.

Stockwell, W. R. and Calvert, J. G.: The mechanism of the HO-SO2 reaction, Atoms. Environ. (1967), 17, 2231-2235, https://doi.org/10.1016/0004-6981(83)90220-2, 1983.

Stockwell, W. R., Lawson, C. V., Saunders, E., and Goliff, W. S.: A Review of Tropospheric Atmospheric Chemistry and Gas-Phase Chemical Mechanisms for Air Quality Modeling, Atmosphere, 3, https://doi.org/10.3390/atmos3010001, 2012.

Su, S-H, Chu, J-L, Yo, T-S, Lin, L-Y.: Identification of synoptic weather types over Taiwan area with multiple classifiers, Atmos. Sci. Lett., 19, e861, https://doi.org/10.1002/asl.861, 2018.

Tsona, N. T., Li, J., and Du, L.: From O2--Initiated SO2 Oxidation to Sulfate Formation in the Gas Phase, J. Phys. Chem. A, 122, 5781-5788, https://doi.org/10.1021/acs.jpca.8b03381, 2018.

Wang, S., Zhou, S., Tao, Y., Tsui, W. G., Ye, J., Yu, J. Z., Murphy, J. G., McNeill, V. F., Abbatt, J. P. D., and Chan, A. W. H.: Organic Peroxides and Sulfur Dioxide in Aerosol: Source of Particulate Sulfate, Env. Sci. \& Technol., 53, 10695-10704, https://doi.org/10.1021/acs.est.9b02591, 2019.

Wendisch, M., Pöschl, U., Andreae, M. O., Machado, L. A. T., Albrecht, R., Schlager, H., Rosenfeld, D., Martin, S. T., Abdelmonem, A., Afchine, A., Araùjo, A. C., Artaxo, P., Aufmhoff, H., Barbosa, H. M. J., Borrmann, S., Braga, R., Buchholz, B., Cecchini, M. A., Costa, A., Curtius, J., Dollner, M., Dorf, M., Dreiling, V., Ebert, V., Ehrlich, A., Ewald, F., Fisch, G., Fix, A., Frank, F., Fütterer, D., Heckl, C., Heidelberg, F., Hüneke, T., Jäkel, E., Järvinen, E., Jurkat, T., Kanter, S., Kästner, U., Kenntner, M., Kesselmeier, J., Klimach, T., Knecht, M., Kohl, R., Kölling, T., Krämer, M., Krüger, M., Krisna, T. C., Lavric, J. V., Longo, K., Mahnke, C., Manzi, A. O., Mayer, B., Mertes, S., Minikin, A., Molleker, S., Münch, S., Nillius, B., Pfeilsticker, K., Pöhlker, C., Roiger, A., Rose, D., Rosenow, D., Sauer, D., Schnaiter, M., Schneider, J., Schulz, C., de Souza,

R. A. F., Spanu, A., Stock, P., Vila, D., Voigt, C., Walser, A., Walter, D., Weigel, R., Weinzierl, B., Werner, F., Yamasoe, M. A., Ziereis, H., Zinner, T., and Zöger, M.: ACRIDICON-CHUVA Campaign: Studying Tropical Deep Convective Clouds and Precipitation over Amazonia Using the New German Research Aircraft HALO, B. Am. Meteorol. Soc., 97, 1885-1908, https://doi.org/10.1175/BAMS-D-14-00255.1, 2016. 
https://doi.org/10.5194/acp-2021-788

Preprint. Discussion started: 25 October 2021

(c) Author(s) 2021. CC BY 4.0 License.

(c) (i)
Atmospheric

Chemistry

$\frac{\text { and Physics }}{\text { Discussions }}$

Yang, Y., Shao, M., Keßel, S., Li, Y., Lu, K., Lu, S., Williams, J., Zhang, Y., Zeng, L., Nölscher, A. C., Wu, Y., Wang, X., 455 and Zheng, J.: How the $\mathrm{OH}$ reactivity affects the ozone production efficiency: case studies in Beijing and Heshan, China, Atmos. Chem. Phys., 17, 7127-7142, https://doi.org/10.5194/acp-17-7127-2017, 2017.

Ye, J., Abbatt, J. P. D., and Chan, A. W. H.: Novel pathway of SO2 oxidation in the atmosphere: reactions with monoterpene ozonolysis intermediates and secondary organic aerosol, Atmos. Chem. Phys., 18, 5549-5565, https://doi.org/10.5194/acp-185549-2018, 2018.

460 Zahn, A., Weppner, J., Widmann, H., Schlote-Holubek, K., Burger, B., Kühner, T., and Franke, H.: A fast and precise chemiluminescence ozone detector for eddy flux and airborne application, Atmos. Meas. Tech., 5, 363-375, https://doi.org/10.5194/amt-5-363-2012, 2012. 
https://doi.org/10.5194/acp-2021-788

Preprint. Discussion started: 25 October 2021

(c) Author(s) 2021. CC BY 4.0 License.
Atmospheric

Chemistry

and Physics

Discussions

ò

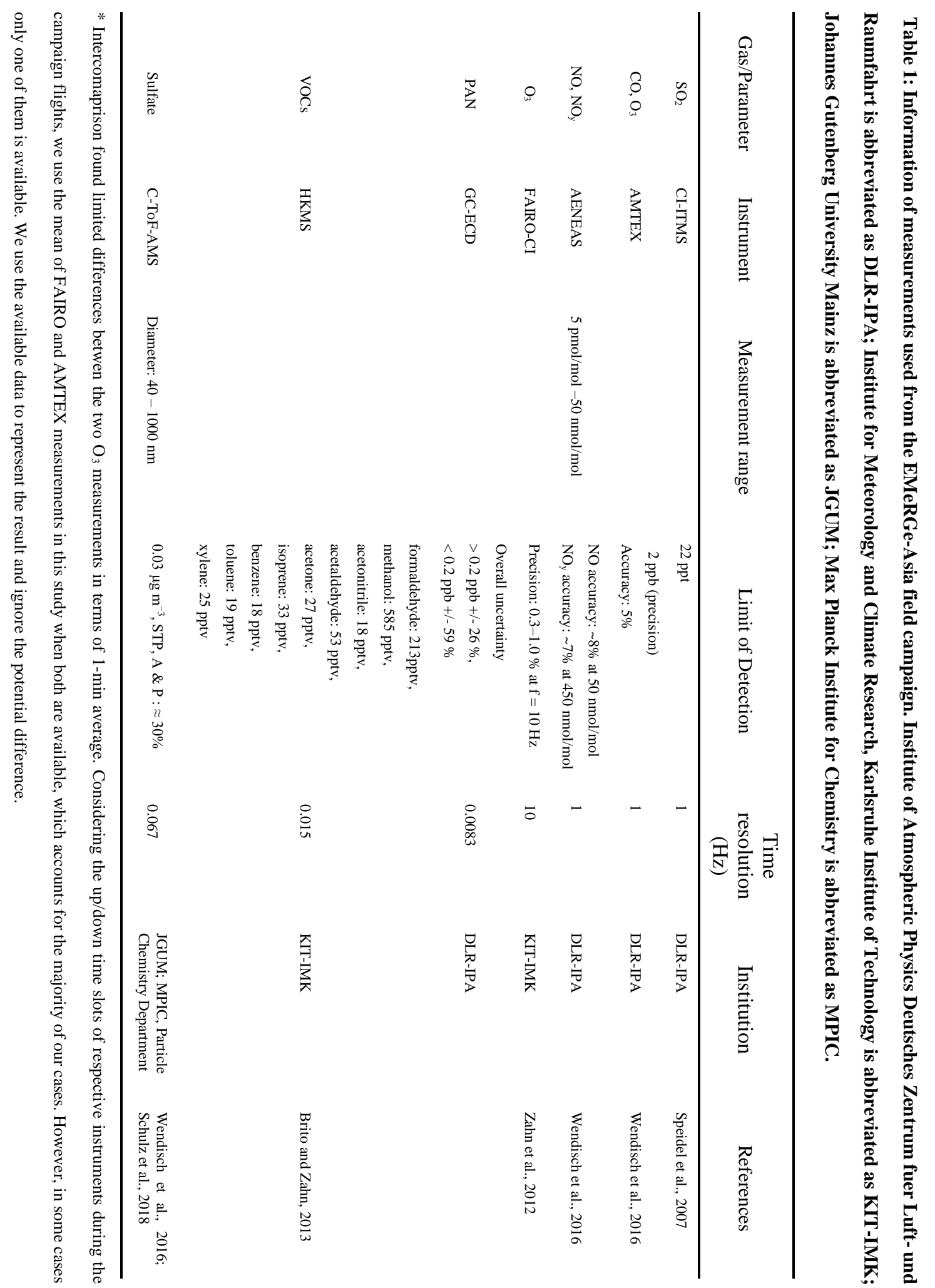


Table 2: $\mathrm{SO}_{2}$ gas-phase-produced sulfate (SGS) percentage at different altitudes and areas.

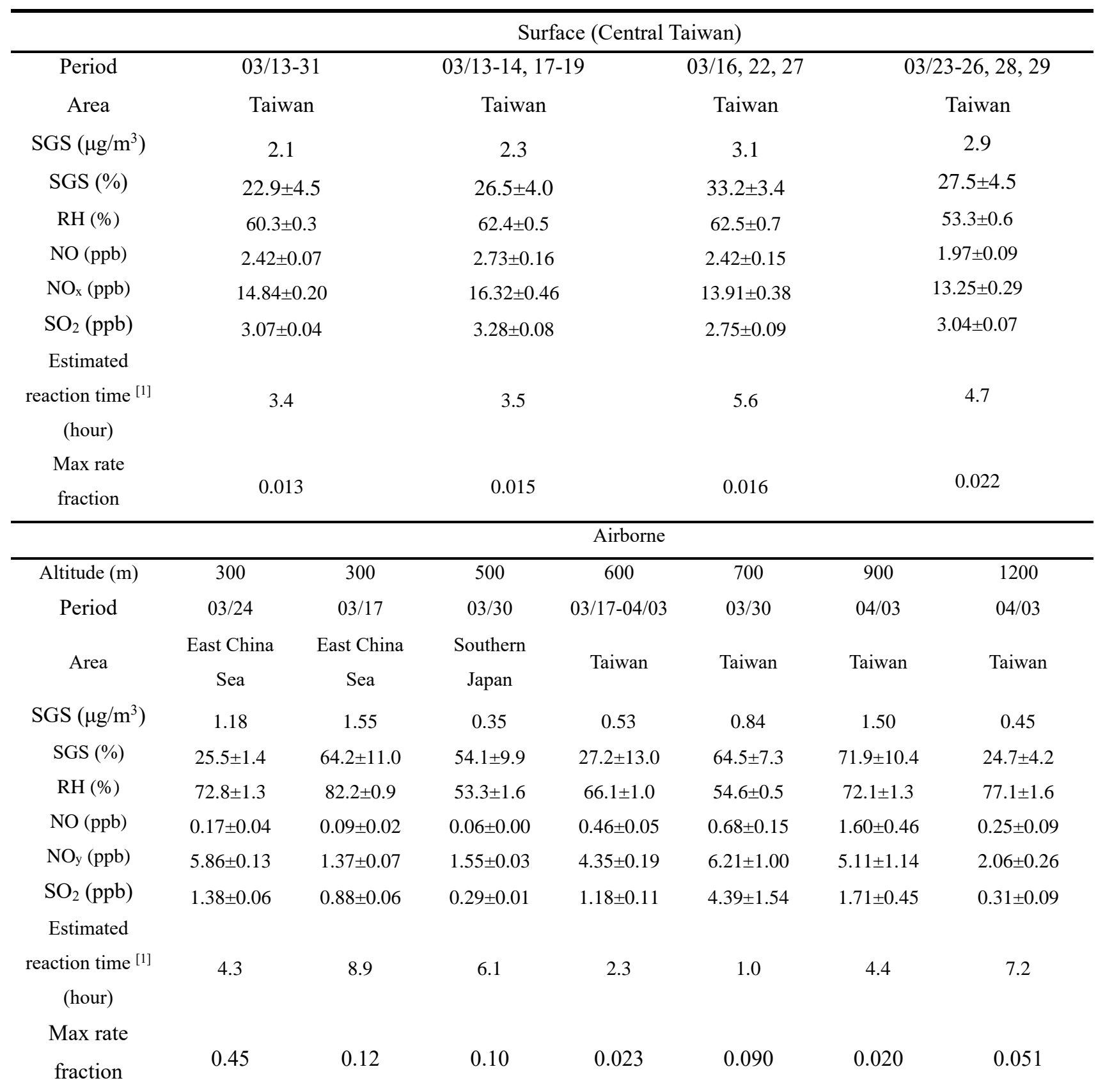

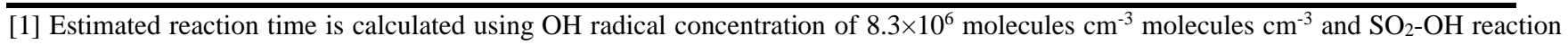
rate coefficient of $1.7 \times 10^{-12} \mathrm{~cm}^{3}$ molecule $\mathrm{s}^{-1}$. 
https://doi.org/10.5194/acp-2021-788

Preprint. Discussion started: 25 October 2021

(c) Author(s) 2021. CC BY 4.0 License.

(c) (1)
Atmospheric

Chemistry

and Physics

Discussions

475
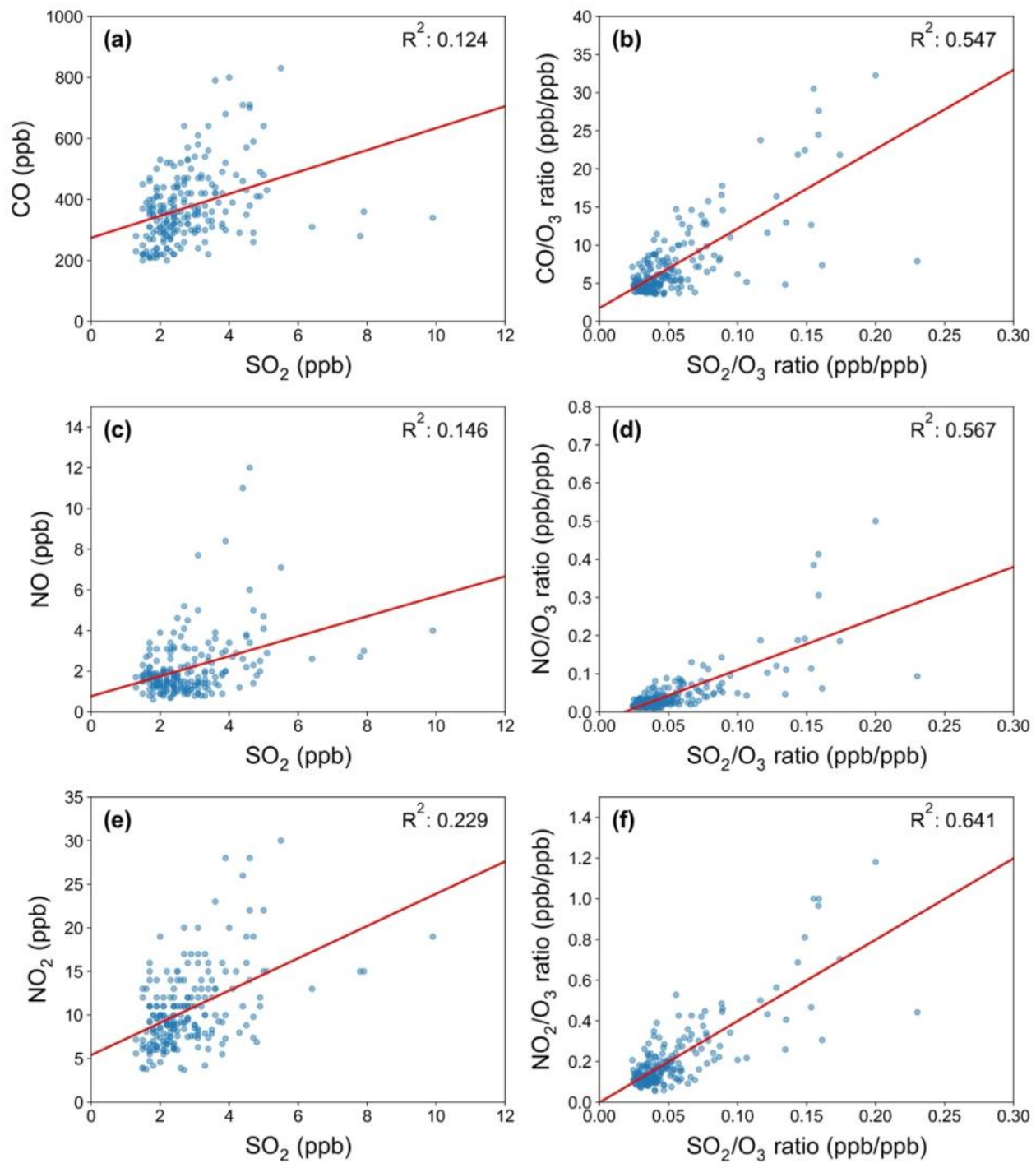

Figure 1: $\mathrm{CO}_{-} \mathrm{SO}_{2}(\mathrm{a}, \mathrm{b}), \mathrm{NO}-\mathrm{SO}_{2}(\mathrm{c}, \mathrm{d})$, and $\mathrm{NO}_{2}-\mathrm{SO}_{2}(\mathrm{e}, \mathrm{f})$ relationships before $(\mathrm{a}, \mathrm{c}, \mathrm{e})$ and after $(\mathrm{b}, \mathrm{d}, \mathrm{f})$ the $\mathrm{O}_{3}$ normalization of Tainan station. 

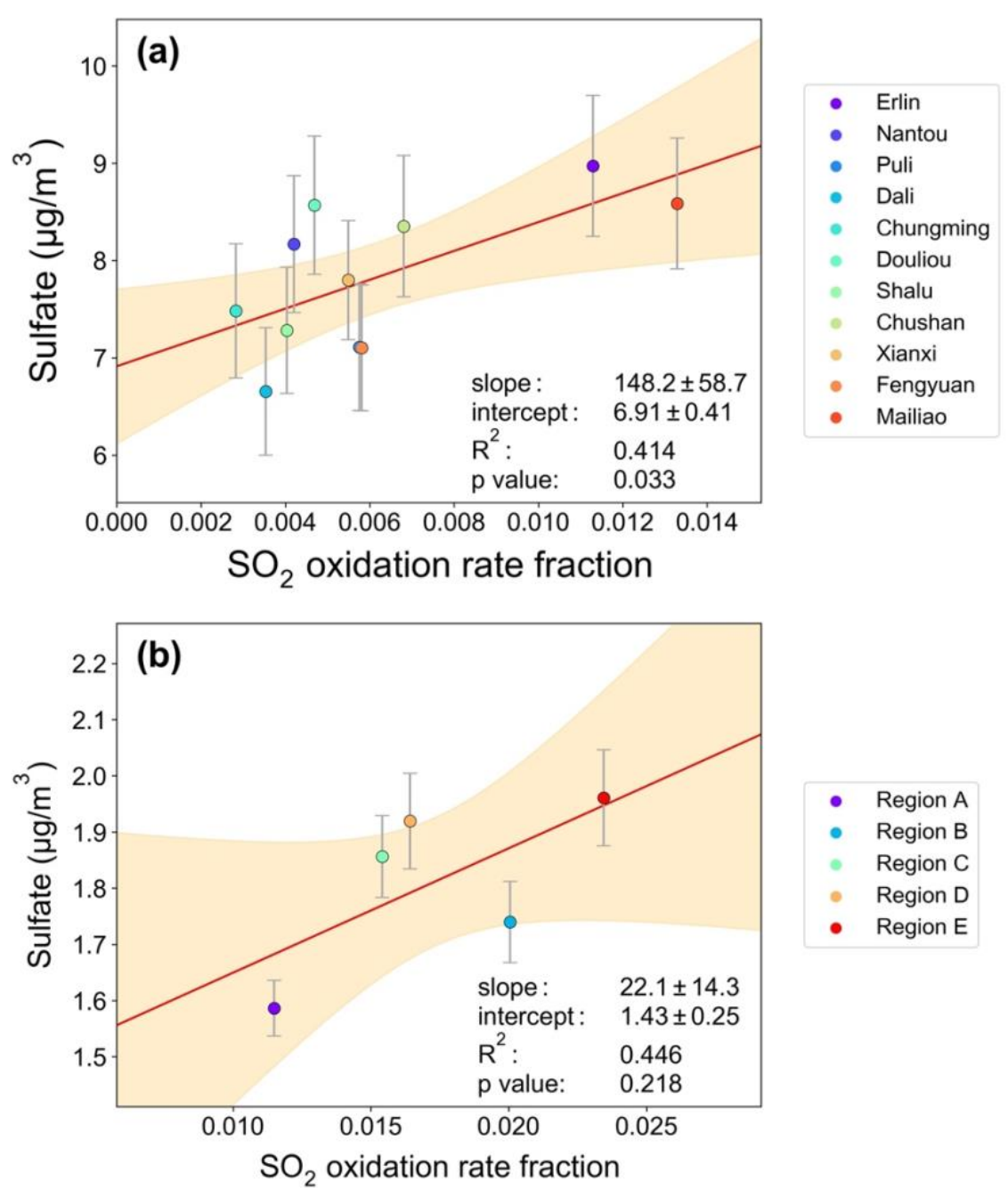

Figure 2: Relationships between sulfate concentrations and $\mathrm{SO}_{2}$ oxidation fraction of rate of loss of OH of (a) Surface EPA stations during March 13th to 31st, 2018 and (b) airborne observation from March 17th to April 7th, 2018 (b). Fitting lines are plotted in solid red lines with orange shades of $95 \%$ confidential interval. 
https://doi.org/10.5194/acp-2021-788

Preprint. Discussion started: 25 October 2021

(c) Author(s) 2021. CC BY 4.0 License.

(c) (i)
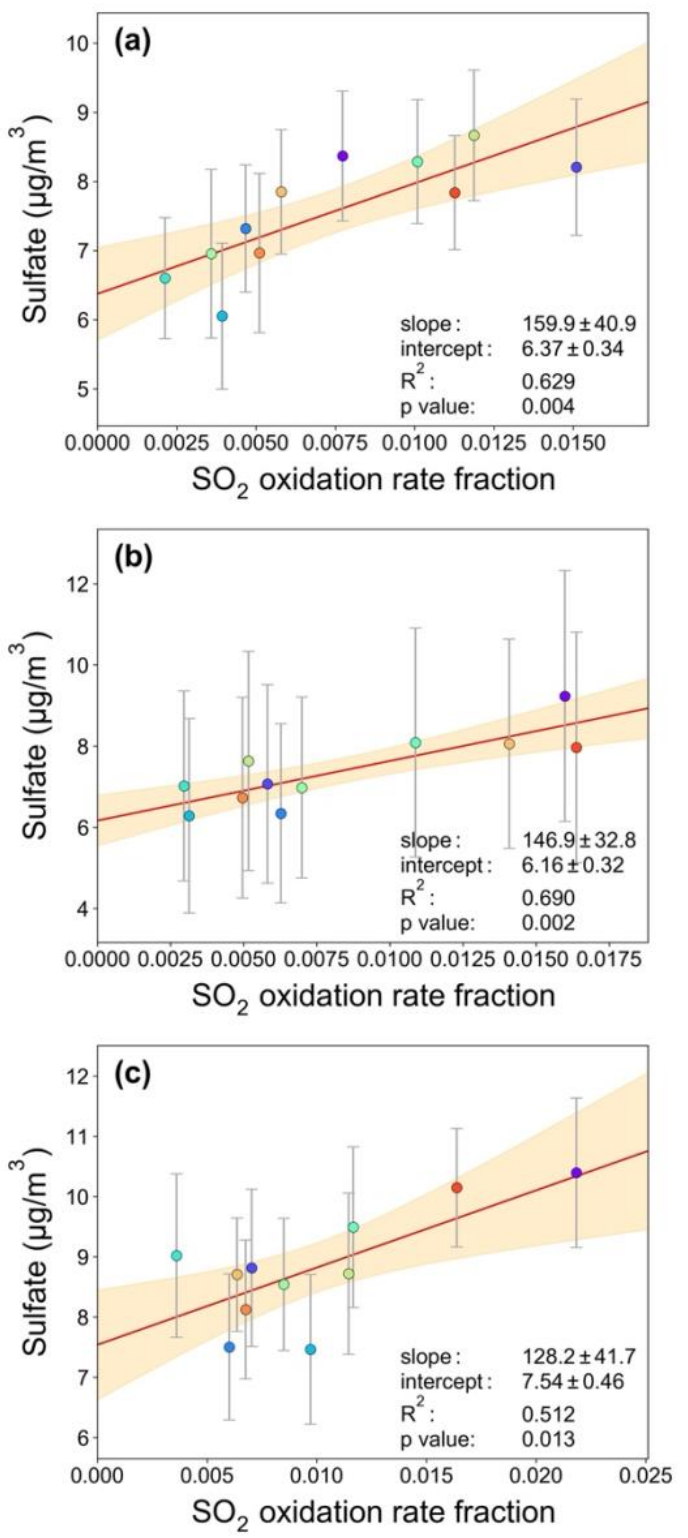

Figure 3: Relationships between sulfate concentration and $\mathrm{SO}_{2}$ oxidation fraction of the rate of $\mathrm{OH}$ loss using equation 9 based on surface measurements. The first period (a) consists of March $13^{\text {rd }}, 14^{\text {th }}$, and $17^{\text {th }}-19^{\text {th }}$, representing the southwesterly flow. The second period (b) includes March $16^{\text {th }}, 22^{\text {nd }}$, and $27^{\text {th }}$, which serves as the northeasterly flow. The third period (c) corresponds to March $23^{\text {rd }}-26^{\text {th }}, 28^{\text {th }}$, and $29^{\text {th }}$, representing weak synoptic weather events. 

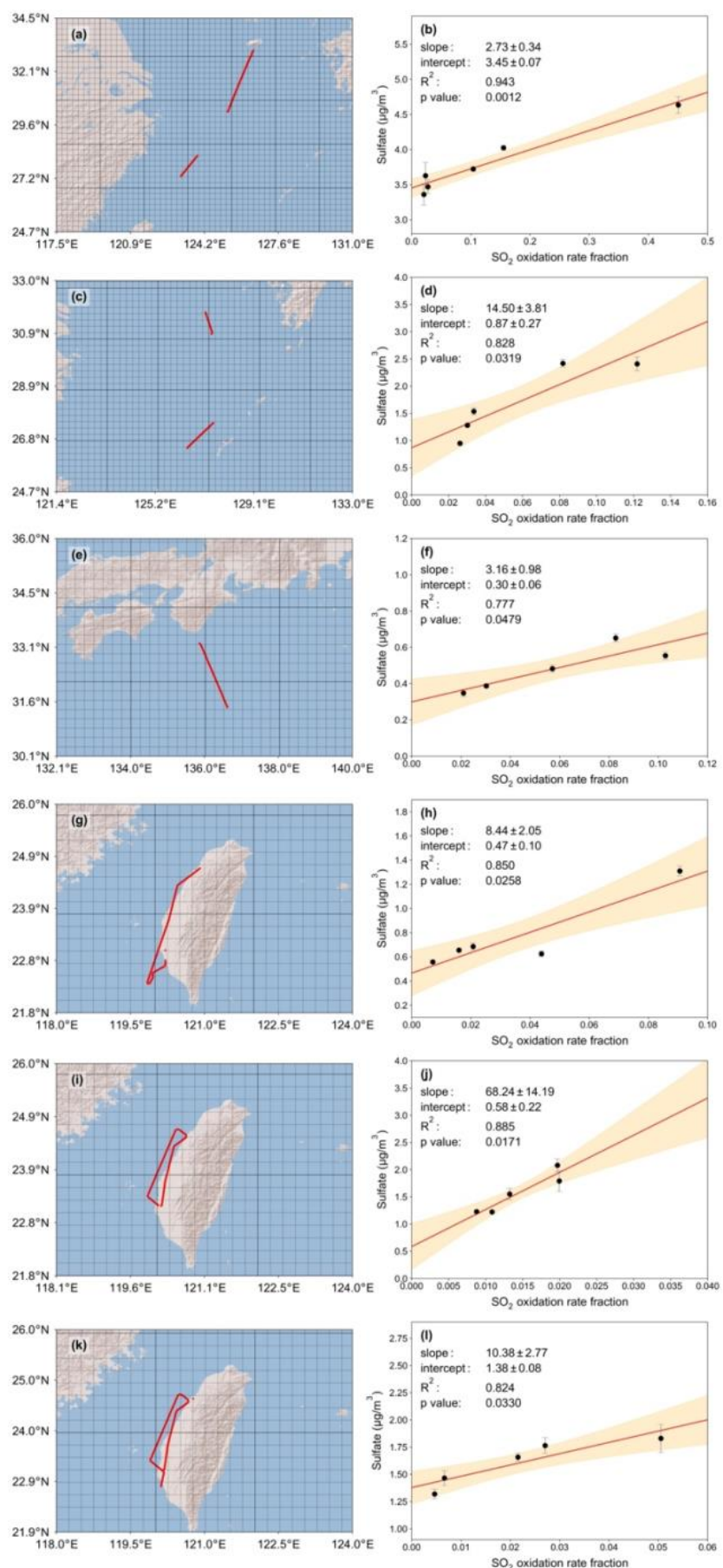

Figure 4: Flight path of data (left) utilized to calculate the correlation of sulfate and $\mathrm{SO}_{2}$ oxidation fraction of the rate of loss of $\mathrm{OH}$ (right). The altitudes of the flights are (a, b) $300 \mathrm{~m},(\mathrm{c}, \mathrm{d}) 300 \mathrm{~m},(\mathrm{e}, \mathrm{f}) 500 \mathrm{~m},(\mathrm{~g}, \mathrm{~h}) 700 \mathrm{~m},(\mathrm{i}, \mathrm{j}) 900 \mathrm{~m}$, and $(\mathrm{k}, \mathrm{l}) 1200 \mathrm{~m}$, respectively. Noted that a 15-second average dataset (instead of a 1-minute average in the previous analysis) is utilized here. The maps were generated using the Matplotlib Basemap Toolkit version 1.2.0 (https://matplotlib.org/basemap/index.html). 

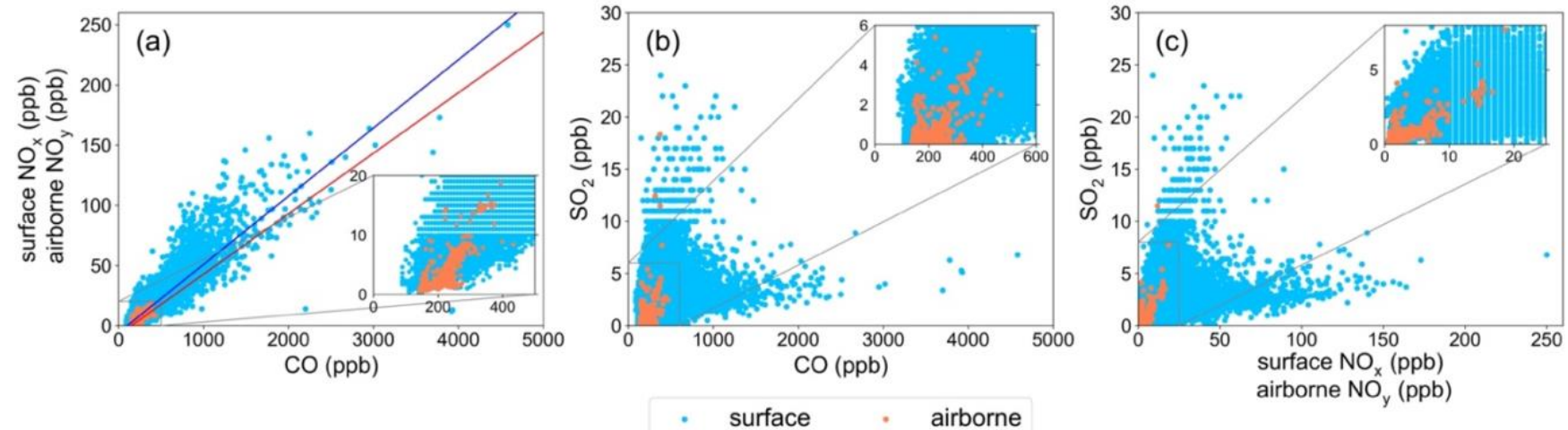

Figure 5: Relationship of ground-based (in blue) and airborne (in red) measurements of (a) $\mathrm{NO}_{\mathrm{x}}$ to $\mathrm{CO}$ and $\mathrm{NO}_{\mathrm{y}}$ to $\mathrm{CO}$, respectively, (b) $\mathrm{SO}_{2}$ to $\mathrm{CO}$, and (c) $\mathrm{SO}_{2}$ to $\mathrm{NO}_{\mathrm{x}}$ and $\mathrm{SO}_{2}$ to $\mathrm{NO}_{\mathrm{y}}$, respectively. The slopes of regression lines of surface $\mathrm{NO}_{\mathrm{x}}$ to $\mathrm{CO}$ and airborne $\mathrm{NO}_{\mathrm{y}}$ to $\mathrm{CO}$ in $3 \mathrm{a}$ are $0.057 \pm 0.0003$ and $0.050 \pm 0.002$, respectively.
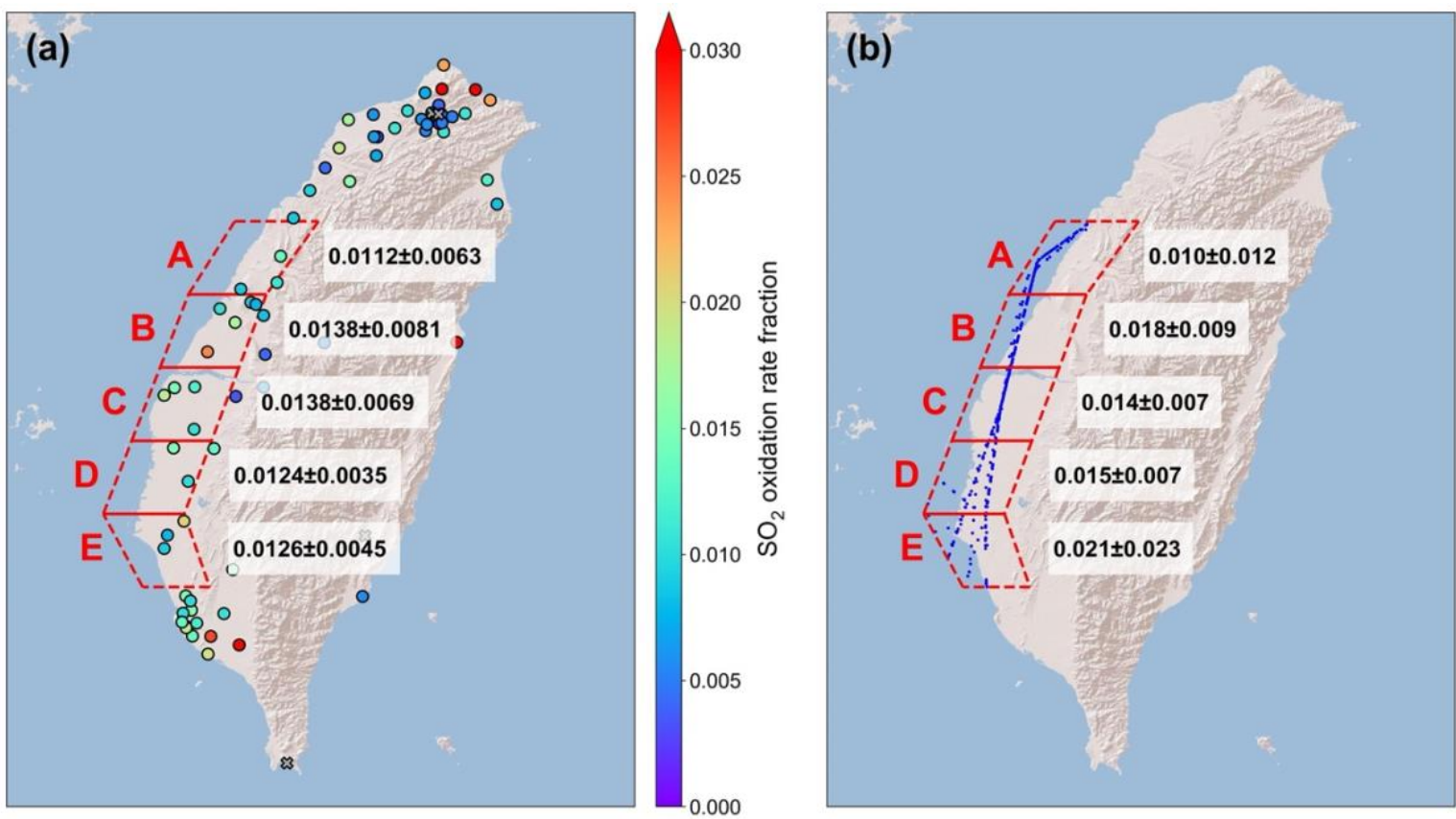

Figure 6: The average $\mathrm{SO}_{2}$ oxidation fractions of the rate of loss of $\mathrm{OH}$ for the selected regions at the surface (a) and in the air (b). Scatter points in (a) show the $\mathrm{SO}_{2}$ oxidation fraction of the rate of loss of $\mathrm{OH}$ at each EPA station. The flight tracks at $600 \mathrm{~m}$ are indicated as blue scattered lines in (b). The maps were generated using the Matplotlib Basemap Toolkit version 1.2.0 (https://matplotlib.org/basemap/index.html). 